\title{
Novela: um gênero polêmico
}

Peterson José de Oliveira*

A teoria da novela é um dos temas dos estudos literários mais negligenciados até hoje. Num breve e despretensioso apanhado da bibliografia sobre o assunto, pudemos perceber a incapacidade de os autores encontrarem termos comuns para definir tal gênero textual, o que gera a questão: se a pureza dos gêneros literários não é mais exigida, por que os autores seguem nomeando seus textos ainda? Mesmo assim, evidencia-se certo preconceito quanto à qualidade desse gênero, uma vez que os autores destacam sua suposta superficialidade em relação ao conto e ao romance, opinião expressa pelo crítico brasileiro que mais atenção deu ao gênero, Massaud Moysés.

Palavras-chave: Gênero literário. Novela. Crítica literária.

The theory of the novel is one area most neglected of literary studies today. In a brief and unpretentious overview of literature on the subject, we realized the inability of authors to find common terms to define this genre, which leads to the question: if the purity of literary genres is no longer required that authors follow the naming his texts yet? Even so, it is clear certain prejudice about the quality of this kind, since the authors highlight their supposed superficiality in relation to the story and the novel, a view expressed by the Brazilian critic who gave greater attention to gender, Massaud Moses.

Keywords: Literary genre. Novel. Literary criticism.

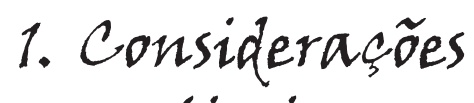
preliminares

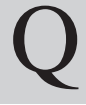

uem se aventurar em pesquisas sobre as características do gênero novela certamente irá notar o quão pouco o assunto é abordado pelos teóricos da literatura, se comparado com os inúmeros estudos, muitos já clássicos, sobre romance ou o conto. Na maior parte dos casos, as diferenças são estabelecidas entre romance e conto; geralmente quando aludem à novela, referem-se às novelas de cavalaria Os principais manuais de teoria literária estendem-se longamente ao tratar do romance e do conto; se da novela falam, resumem-se a breves comentários de cunho geral ${ }^{1}$. Nessa perspectiva, a novela seria tida então como um gênero menor. Podemos pensar também que o motivo desse aparente menospre-

\footnotetext{
* Mestre em Linguística pelo Programa de Pós-Graduação em Liguística do Instituto de Letras e Lingüística da Universidade Federal de Uberlândia. peterol@bol.com.br

${ }^{1}$ Em sua Teoria da literatura, Vítor Manuel de Aguiar e Silva, por exemplo, trata do romance em 99 páginas, enquanto fala da novela em um parágrafo, em meia página. Ver SILVA, Vitor Manuel de Aguiar e. Teoria da literatura. São Paulo: Martins Fontes, 1976.
} 
zo talvez se deva justamente pela complexidade do problema, que começa, aliás, já na etimologia da palavra "novela".

Na contracorrente dos estudos literários sobre gêneros, encontramos um estudo do crítico Massaud Moisés ${ }^{2}$, cuja abordagem da novela é feita de forma bastante sistemática, abrangendo aspectos históricos, conceituais, estruturais, que na maioria das vezes aparecem misturados a avaliações de natureza subjetiva, julgamentos que focalizam a beleza do texto, a originalidade, a complexidade da visão de mundo instaurada pelo gênero novela. Moisés oscila, assim, em sua análise entre dois pontos de vista: de um lado, busca os elementos constitutivos desse gênero; de outro, tece críticas severas quanto à sua excelência artística se o compararmos com o romance ou o conto. Como será visto mais adiante, a impressão do leitor é de que este crítico, apesar de dedicar 50 páginas para o estudo da novela (muito próximas das 70 destinadas ao conto), não parece disposto a acreditar na dignidade literária desse gênero, associando-o sempre que pode ao baixo nível cultural do público a que ele se destinaria.

Mesmo assim, a análise que esse autor faz do gênero novela é a mais cuidadosa já realizada por um autor brasileiro, o que o torna de suma importância para a elaboração de nosso estudo. De Massau Moisés utilizaremos basicamente suas intuições sobre o conceito e a estrutura da novela, deixando para um segundo plano os aspectos históricos, e trazendo à tona principalmente os aspectos valorativos quando estes interferirem de modo significativo na idéia que temos do gênero. Não nos interessa, portanto, aprofundar a discussão sobre quais elementos trariam a um texto literário a excelência artística, e assim evitamos também trazer essa discussão para um campo muito próximo da crítica literária, que não é o objetivo deste trabalho.

\section{2. os meandros da terminologia}

Ao definir novela, Moisés inicia uma discussão sobre a etimologia da palavra que pareceria ocioso retomar aqui, não fosse por uma observação importante: em outras línguas, a palavra usada como sinônimo de novela pode gerar uma confusão considerável. Etimologicamente a palavra nasce no latim novellus, $a$, um, adjetivo diminutivo do substantivo novus, a, um, o qual significa novo, jovem; o

${ }^{2}$ MOISÉS, Massaud. A criação literária: Prosa I. 16.ed. rev. São Paulo: Cultrix, 2000. 
adjetivo novellus passou a significar muitas coisas, desde chiste e gracejo até os sentidos de enredo e narrativa enovelada . Na língua portuguesa, a palavra novela derivou do italiano novella, significando relato, comunicação, notícia, novidade. A nosso ver, a análise da estrutura novelesca feita por Moisés abarca tanto a questão da novidade quanto a presença do enovelamento do enredo como peças fundamentais da constituição desse gênero. Ao que parece, em outras línguas, a origem latina é preservada.

Se nos mantivéssemos apenas na língua portuguesa, não haveria aparentemente nenhuma confusão entre as três formas mais conhecidas de textos narrativos - romance, novela e conto; todavia, quando acompanhamos o percurso histórico-etimológico da palavra novela em outras línguas, essa divisão tripartite já não é tão pacífica. É o caso do inglês. Nessa língua, segundo Moisés, o termo short-story, na maior parte das vezes, é usado como sinônimo de conto, mas também pode ser aplicado no sentido de novela. Gotlib ${ }^{3}$, entretanto, aponta a existência de um termo específico para denominar a novela: long short story, sugerindo assim uma distinção mais efetiva entre o conto e a novela nos países anglófonos.

Apesar disso, num quadro em que mostra as diversas denominações das formas narrativas em várias línguas, Moisés acaba invalidando parcialmente as distinções que ele mesmo procura estabelecer, quando coloca sob a mesma designação duas entidades literárias diferentes, a novela e o conto literário. O quadro abaixo evidencia essa confusão:

\begin{tabular}{llll}
\hline Inglês & Romance ou Novel & $\begin{array}{l}\text { Novela curta ou } \\
\text { Conto literário }\end{array}$ & $\begin{array}{l}\text { Conto, Conto } \\
\text { popular }\end{array}$ \\
\hline Francês & Roman & Nouvelle & Tale \\
\hline Italiano & Romanzo & Novelle & Conte \\
\hline Alemão & Roman & Novelle ou Erzählung & Racconto \\
Espanhol & Novela & Novela corta & Cuento \\
\hline
\end{tabular}

Ao lermos o quadro, percebemos que Moisés identifica novela curta e conto literário, colocando-os numa mesma designação genérica. Primeiro, porque não

${ }^{3}$ GOTLIB, Nádia Batella. Teoria do conto. 7.ed. São Paulo: Ática, 1995. 
existe no português um gênero denominado novela curta; possivelmente para ele novela curta é o que chamamos simplesmente novela. Essa confusão certamente foi criada por conta de uma tradução literal do termo novela corta, que em espanhol significa provavelmente o que chamamos novela. Assim, o crítico aparentemente invalida sua distinção entre conto e novela, pois os coloca juntos numa mesma célula de seu quadro. Depois, na seção do quadro dedicada ao conto, o autor não especifica qual a diferença entre conto popular e conto artístico.

Uma questão com que se depara qualquer um que pretenda estudar o problema da nomenclatura dessas três formas literárias é o fato de que historicamente existe um trânsito intenso dos termos que designam novela, romance e conto. É o caso, por exemplo, do termo romance que, em inglês designava, do século XVI ao XVIII, uma narrativa mais longa, mais tradicional e de origem medieval. No século XIX, esse termo é substituído por outro já existente - novel, que até então designava a prosa narrativa de ficção, com personagens ou ações representando a vida diária. Como aponta Gotlib , o vocábulo novel preencheu o espaço disponível deixado pelo antigo romance, perdeu as associações originais, deixou de ser breve, virou romance. Hoje, novel, em inglês, é aquilo que chamamos em português romance. Além do mais, os autores não parecem muito preocupados em obedecer a tais categorizações, chamando, quando lhes parece melhor, suas novelas de contos. Gotlib fala de Maupassant, que chama suas nouvelles (as nossas novelas) de contes (o que chamamos contos).

No caso de Valêncio Xavier, aconteceu um fato semelhante. Numa entrevista, ao se referir ao seu processo de criação, o autor chama os textos que compõem o volume $O$ mez da grippe de contos, mesmo que pelo menos dois tenham sido classificados na página de rosto como novelas: “ A Companhia das Letras lançou, em setembro, meus quatro primeiros livros e um inédito, num volume só, com o título O Mez da Grippe e outros livros. [...] São contos que, pelo menos na minha cabeça, tratam de enigmas que me incomodam"4 [itálico nosso].

Ao teorizar sobre o conto, Gotlib alude de passagem àquilo que denominamos novela, contrapondo-a ao conto e ao romance; porém, ao fazer um recenseamento histórico sobre as origens do conto, a autora irá utilizar inúmeras vezes o

\footnotetext{
${ }^{4}$ XAVIER, Valêncio. O Minotauro. In: XAVIER, Valêncio. O mez da grippe e outros livros. São Paulo: Companhia das Letras, 2002.
} 
termo novela significando conto literário, em contraposição ao conto tradicional ou folclórico, que teria origem oral, sem a marca do eu criador, e caráter maravilhoso. A novela seria assim uma espécie de protótipo a partir do qual os contos modernos teriam surgido. Para fundamentar sua argumentação, a autora vai à teoria das formas simples de André Jolles, onde encontramos tal distinção ancorada na expressão da individualidade, constituindo um dos primórdios da autoria. A novela seria então um primeiro momento em que um autor-criador aparece individualizado:

Novela é que é, para Jolles, a 'forma artística', que poderia corresponder ao nosso atual conto literário. Porque a novela leva a marca do eu criador, é produto de uma personalidade em ação criadora, que tenta representar uma parcela peculiar da realidade, segundo seu ponto de vista único, compondo um universo fechado e coeso, sólido ${ }^{5}$.

Para nós, está claro que a autora também percebeu a flutuação terminológica dos termos novela e conto. Ainda comentando a teoria de Jolles, ao analisar o Decameron de Bocaccio (chamado aí de novela toscana), a autora vai se referir a essa obra como uma narrativa de moldura: narrativas ligadas por uma espécie de quadro onde se assinalam o lugar, o momento e os narradores. Entretanto, observe-se a maneira como Gotlib desenvolve tal pensamento:

Esta novela toscana adotou também o procedimento da narrativa de moldura, que já existia anteriormente e que vai persistir em muitas coletâneas de contos (ou novelas?): essas narrativas acham-se ligadas por um quadro que assinala, entre outras coisas, onde, quando e por quem são contadas ${ }^{6}$.

É interessante observar que a dúvida da autora, expressa na interrogação entre parênteses, já havia aparecido algumas páginas atrás ao se referir ao mesmo Decameron, quando ela os denomina "contos eróticos de Bocaccio". Encerrando esse tópico da discussão, a autora deixa muito clara então uma idéia evolutiva: do conto simples ou maravilhoso teriam surgido os contos artísticos, chamados a princípio de novelas toscanas e de moldura.

Ao leitor deste trabalho pode parecer desnecessária tanta controvérsia a respeito da terminologia, entretanto, ao procurarmos nos autores consagrados

\footnotetext{
${ }^{5}$ GOTLIB, Nadia Batella. Op. cit., p. 18.

${ }^{6}$ Idem, P. 19.
} 
teorizações sobre a forma narrativa chamada novela, encontramos com esse nome o que é indiscutivelmente o conto. É o caso de Eikhenbaum ${ }^{7}$. Em seu artigo Sobre a teoria da prosa, o autor faz um estudo comparativo entre o romance e a novela. O que encontramos, em todo caso, é uma comparação entre romance e conto. Isso fica claro quando ele faz uma análise da prosa americana do século XIX. Nesse momento, Eikhenbaum usa o termo short story como sinônimo de novela; entretanto, em português, short story corresponde ao conto:

Na América, muito mais que em outra parte, cultiva-se a novela curta (short story) [...] A década de 30 e 40 do século XIX mostrou claramente a tendência da prosa americana para desenvolver o gênero da novela (short story) ${ }^{8}$.

Também não descartamos a hipótese de que possa ter havido um erro de tradução. O termo short story certamente está no original russo, ou mesmo na versão usada pelos tradutores brasileiros. De qualquer modo, isso só confirma nosso raciocínio: a flutuação não é apenas terminológica; até mesmo para os que lidam com esses problemas teóricos, as narrativas conto e novela não são tão diferentes assim; e talvez por isso eles não vêem problemas em identificar os dois termos.

Para que não paire nenhuma dúvida de que Eikhenbaum fala apenas do conto, transcrevemos abaixo o momento em que essa coincidência dos termos novela e conto é flagrante. Como sabemos, Edgar Allan Poe é reconhecido tradicionalmente como um dos criadores do conto moderno, além de ser também um teórico desse tipo de narrativa9 ${ }^{9}$ Na citação a seguir, Eikhenbaum afirma que Poe caracteriza o gênero novela. Porém, logo no começo da citação de Poe, este escritor irá apresentar como um escritor habilidoso deverá proceder ao compor um conto:

No final, Poe caracteriza o gênero da novela: "Um escritor hábil construiu um conto. Se ele conhece seu trabalho, não modelou seus pensamentos sobre os incidentes, mas depois de haver concebido com cuidado e reflexão um certo efeito único que se propõe produzir, inventa incidentes - combina acontecimentos -que lhe permitem

\footnotetext{
${ }^{7}$ EIKHENBAUM, Boris. Sobre a teoria da prosa. In: Teoria da literatura: formalistas russos. 2.ed. Porto Alegre: Globo, 1976.

${ }^{8}$ Idem, p. 163-164.

${ }^{9}$ É o caso dos estudos de Júlio Cortázar, em Alguns aspectos do conto e Poe: o poeta, o narrador e o crítico (In: Valise de cronópio. São Paulo: Perspectiva, 1993), já famosos por suas contribuições ao estudo da obra de Edgar Allan Poe. Nesses estudos, Poe é considerado um dos criadores do gênero conto.
} 
obter esse efeito preconcebido.[...]" Poe tinha o hábito de escrever suas novelas começando-as pelo fim, assim como os chineses escrevem seus livros ${ }^{10}$.

Ao citar Poe, Eikhenbaum mostra que o autor norte-americano, em seus textos críticos, caracteriza o gênero novela. "Poe caracteriza o gênero novela: 'Um escritor hábil construiu um conto' " (grifo nosso). Nesse momento fica evidente que ambos falam da mesma coisa, apesar de o nome usado ser diferente.

Aparentemente, para o tradutor do livro em que se encontra o texto de Eikhenbaum, não haveria prejuízo em usar um ou outro termo; acontece que em um estudo como o nosso essa distinção é fundamental; do contrário, nem poderíamos falar de um gênero específico chamado novela, no sentido moderno do termo, ou seja, como uma narrativa diferente do conto e do romance. Aumenta ainda mais tal confusão o fato de que existem pouquíssimos textos tratando do assunto, e este trabalho de Eikhenbaum é constantemente citado como obra de referência no estudo da novela e não do conto.

Esse deslizamento dos termos se torna mais intenso nos gêneros literários limítrofes, quando autores analisam comparativamente a novela e o romance. Não há, por exemplo, a substituição livre de um termo que designa conto para um termo que designa romance, como acontece com o uso de novela e conto para se referir ao mesmo tipo de narrativa. Quando os contornos entre os gêneros se esmaecem, a nomenclatura que os designa fica confusa, porque tratamos de textos com muitas características comuns. Assim, a novela (agora não mais no sentido usado por Eikhenbaum, mas no sentido que modernamente lhe atribuímos) seria um gênero que em alguns aspectos é fronteiriço com o romance e em outros, com o conto. Portanto, no estudo da novela feito por Moisés, o leitor tem a nítida sensação de que as narrativas usadas pelo autor como exemplos de novelas são na verdade romances. É o caso $O$ tempo e o vento, obra de Érico Veríssimo ${ }^{11}$, ou de Memórias de um sargento de milícias, de Manuel Antônio de Almeida ${ }^{12}$. Tais obras, para a maioria absoluta da crítica, são indiscutivelmente romances. ${ }^{13}$

${ }^{10}$ EIKHENBAUM, Boris. Op. cit., p. 165.

${ }^{11}$ VERÍSSIMO, Érico. O tempo e o vento. 10a . Ed. São Paulo: Cia. das Letras. 2009.

${ }^{12}$ ALMEIDA, Manuel Antônio de. Memórias de um sargento de milícias. São Paulo: Ática, 2004.

${ }^{13}$ Antonio Candido, em obra de referência, Formação da literatura brasileira, irá chamar Memórias de um sargento de milícias de "romance de moto-contínuo" Ver CANDIDO, Antônio. Manuel Antônio de: o romance em moto-contínuo, in: Formação da literatura brasileira. $8^{\circ}$ ed. v. 2. Belo Horizonte; Rio de Janeiro: Itatiaia, 1997, p. 195-199. 
Outros, ainda, definem novela por um critério quantitativo: a extensão da obra. Nessa acepção, a novela seria uma narrativa de ficção de extensão média (maior que o conto, menor que o romance), com um número de páginas variando entre 100 e 200. Tavares ${ }^{14}$ aponta que "costumam os autores fazer distinção entre o romance, a novela e o conto pela extensão de cada uma dessas espécies. O romance seria a obra mais longa, a novela menos longa que o romance e mais extensa que o conto". Tal critério, refutado tanto por Moisés quanto por Tavares, não nos parece tão absurdo, apesar de ser pouco produtivo em termos de análise. Existe, sim, uma intuição da parte de leitores e autores a respeito da extensão das narrativas; o tamanho delas seria um critério de classificação genérica mesmo que imperfeito. Ao consultar o mencionado estudo de Eikhenbaum, encontramos talvez a origem dessa confusão.

O notório lingüista russo faz um estudo da narrativa, definindo e contrapondo dois tipos de textos literários: a novela e o romance. A primeira teria dimensões reduzidas, é baseada num erro, mistério, conflito; tende para a conclusão, num final culminante. O segundo, por sua vez, caracteriza-se justamente por suas grandes dimensões; por 'diminuir a ação'; trabalhar com episódios paralelos e não terminar com a resolução das intrigas, mas continuar ainda num 'epílogo'; em suma, para o romance o final é atenuado e pode mesmo ser antecipado.

\section{Conceito, estrutura e evolução da novela em Massaud Moisés}

A caracterização de novela em Moisés é, de maneira geral, negativa. Esse gênero frequentemente é apresentado comparado ao romance, em relação ao qual sempre se mostra deficiente, menor. Para o autor parece haver clara uma hierarquia entre os gêneros, ficando a novela em prejuízo se cotejada com o romance ou o conto. Numa primeira definição a novela é apresentada como uma narrativa de aventuras, superficial, feita para extravasar os desejos de fantasia e evasão de um público pouco exigente; a superficialidade apontada nessas narrativas seria um reflexo da superficialidade da própria massa de leitores a que se destinam. Assim, a

${ }^{14}$ TAVARES, Hênio. Teoria literária. 7.ed. Belo Horizonte: Itatiaia, 1981, p. 122. 
descrição do gênero é permeada de modo implícito por uma hierarquização dos gêneros, encontrando-se o romance no topo dessa classificação.

Ora, o fato de a novela fantasiar, fingir, não questionar, como aponta o autor, corrobora uma visão negativa da fantasia, negando-lhe as potencialidades simbólicas e as reverberações do inconsciente encontradas nas narrativas fantásticas. É comum que alguns escritores, pressionados pelas expectativas do público consumidor, utilizam-se de esquemas repetitivos de enredo, de caracterização, induzindo a um empobrecimento da narrativa pelo uso contínuo de estereótipos. Entretanto, tal estereotipagem não é exclusiva da novela: há pastiches de contos, de poemas líricos, há os epígonos em todos os gêneros que, por falta de originalidade ou mesmo por conta de um certo oportunismo, só arranham a superfície da capacidade criativa da imaginação.

Fantasiar pode ser um jogo importante para o aparecimento das pulsões mais profundas do inconsciente. Há mesmo toda uma tradição literária que se fundamenta na libertação das amarras do real, na era moderna começando talvez com os românticos e simbolistas, chegando até os surrealistas. A verdade revelada pelo relato fantástico é simbólica, não uma verdade histórica ou social, que mimetize estruturas econômicas e políticas. Desse modo, acontecimentos maravilhosos e impossíveis, "aventurescos" (para usar a expressão pejorativa em Massaud Moisés) presentes nas novelas e nos mitos podem traduzir arquétipos do comportamento humano.

Basicamente todo o percurso analítico de Massaud Moisés, quando este se dispõe a elencar os elementos estruturais da novela, aponta para uma hierarquização clara: o que é fundamental no gênero novelesco é que este se destina a entreter a massa, um público pouco exigente, sequioso para dar vazão a sua imaginação. Desse modo, as categorias narrativas como tempo, espaço ou personagens aparecem sempre em perspectiva da idéia do destino ou do público a que se destina tal texto. Se não há na novela sutileza na caracterização dos personagens é porque o público a que se dirige não assimilaria personagens com muitas nuances psicológicas; se a ação predomina sobre a investigação psicológica é porque o público também assim o exige. Enfim, tudo se passa como se o autor apenas desejasse satisfazer os desejos do público por distração, não restando a ele mais do que obedecer às receitas de um gênero que, aparentemente já está estabelecido há muito tempo. 
À parte da concepção conservadora de Moisés a respeito do público leitor de novelas, o qual não seria capaz de compreender ou apreciar obras literárias mais complexas, há ainda o problema de caracterizar a novela a partir da noção de público consumidor, porque é difícil falar em narrativas de entretenimento das massas antes do século XVIII ou XIX, uma vez não haver público suficientemente grande para estes textos antes disso. Por consequiência, o autor não se via tolhido a escrever narrativas fantasiosas para agradar a esse público. Logo, não faz sentido pensar as novelas de cavalaria como feitas para agradar a um grande público, se na Idade Média o público leitor típico das novelas - a classe média nem existia.

Além do mais, o raciocínio de Moisés parece refém dessa concepção de texto literário feito para o consumo, para a satisfação das necessidades escapistas do grande público: tudo o que fuja do gosto raso desse público é descartado do gênero; a novela seria então a 'lata de lixo' onde todos os recursos fáceis seriam jogados. O problema da caracterização negativa de novela de Moisés não está na apreciação ou depreciação do gênero, coisa aliás aparentemente indissociável de uma atividade crítica mais conservadora; o problema consiste numa miopia a priori que o impede de enxergar qualquer coisa além da imagem de um público imbecilizado ou carente de estímulos no cotidiano, coagindo o autor a uma obediência cega a receitas literárias.

Segundo tal concepção, o próprio artista - se é que ainda podemos chamá-lo assim - não exerceria qualquer tipo de autonomia sobre sua criação: todos os recursos seriam pré-determinados pela burrice do público, ávido por 'novidades', narrativas mirabolantes que o fizesse esquecer do seu cotidiano cinzento. Se novela é literatura para consumo das massas, o romance não poderia ser também vulgarizado em fórmulas fáceis? Não haveria também público para romances de consumo?

Não negamos ou desconhecemos a influência do leitor na obra que vai ser escrita: ninguém escreve nada sem pensar antes em seu público; isto já é do senso comum nessas discussões. O que preocupa é a atribuição de um papel tão prescritivo do público que torna o autor uma figura meramente decorativa ou um simples manipulador de fórmulas, já que tudo estava previsto desde o início. Assim, o aspecto transgressor que todo artista exercita em relação ao próprio gênero estaria descartado. 
Para Moisés, o ponto fundamental na definição de novela é a ênfase na ação, expressa por meio de uma pluralidade dramática. A novela focaliza diversos conflitos, por meio de um conjunto de células dramáticas ${ }^{15}$, sem que se conceda a nenhuma delas a prerrogativa de ser a principal. Diferentemente do conto, que possui a princípio uma célula dramática, ou do romance que, apesar de possuir várias células dramáticas, destaca apenas uma delas - a do protagonista. Tais células, na novela, seriam relativamente autônomas. A ênfase na ação, no movimento, na peripécia, explica em parte a popularidade desse gênero junto ao público e ao mesmo tempo sua falta de aprofundamento psicológico e falta de verossimilhança, na opinião de Moisés, os principais 'pecados' desse gênero, se comparados com a profundidade da análise do romance.

Outro aspecto característico da novela é a sucessividade das células dramáticas, ou seja, sua ordenação numa ordem seqüencial cronológica linear. Entretanto, essa marca, também chamada de horizontalidade, não é obrigatória para todas as novelas, que podem possuir adiantamentos ou regressões temporais, além de entremeação de episódios. Nas palavras do autor: "A novela forma-se da agregação dessas unidades narrativas, seguindo uma ordenação cronológica, que sugere a perspectiva do mundo fornecida pelo calendário"16.

O autor aponta duas características fundamentais concernentes à ação: a pluralidade dramática e a sucessividade. No tocante à pluralidade dramática, a novela é multívoca, polivalente: contém uma série de unidades ou células dramáticas, focaliza vários conflitos, cada um deles apresentando começo, meio e fim. Segundo Moisés, as unidades dramáticas, contudo, não se comportam como seres autônomos, submetem-se à interação tendo em vista a totalidade narrativa; há um intercâmbio, uma relação de osmose, um entrelaçamento de adição, uma progressão. O caráter de sucessividade estaria no fato de que as células dramáticas

\footnotetext{
15 Massaud Moisés define o que entende por célula dramática ou unidade dramática ao tratar do conto: "Etimologicamente preso à linguagem teatral, 'drama' significava 'ação'. [...] transferido para a prosa de ficção, o termo 'drama' entrou a significar 'conflito', 'atrito'. Nesse caso, 'ação', 'conflito' se tornaram equivalentes, uma vez que toda ação pressupõe conflito, e este, promove a ação, ou por meio dela se manifesta; em suma, ambos se implicam mutuamente. [...] O conto é, pois, uma narrativa unívoca, univalente: constitui uma unidade dramática, uma célula dramática, visto gravitar ao redor de um só conflito, um só drama, uma só ação. (MOISÉS, Massaud. Op.cit., p. 40).
}

${ }^{16}$ MOISÉS, Massaud. Op. cit.. 
obedecem a uma ordem seqüencial, dispostas uma após a outra, em rosário. Tal sucessividade, entretanto, não é absoluta, pois o escritor, como forma de manter o interesse do leitor, não esgota o conteúdo de uma célula antes começar a seguinte, para que se tenha um imbricamento das mesmas.

A sucessividade da novela também se caracteriza pela substituição dos personagens ao longo da trama. Desse modo, um personagem que era protagonista numa novela, na sequiência da mesma ocupará um segundo plano, sendo substituído por um secundário que passa então a protagonista. $\mathrm{O}$ escritor teria a liberdade de continuar quase infinitamente a trama, por meio da sucessão de grupos de personagens. Neste momento a argumentação de Moisés deixa claro que os ciclos novelescos de que fala usam essa sucessividade do gênero. De todo modo, tal compreensão da novela vai na contramão de um senso mais generalizado sobre este gênero, segundo o qual as novelas são narrativas de menor fôlego que o romance.

Na visão do autor, a novela se forma, por conseguinte, da agregação dessas unidades narrativas, segundo uma ordenação cronológica que sugere a perspectiva do mundo fornecida pelo calendário, ou seja, constitui uma multiplicidade dramática numa corrente horizontal. A ação na novela possui para Moisés duas características fundamentais: a pluralidade dramática e a sucessividade. Quanto à primeira, há um problema a se destacar: muitas células dramáticas equivaleriam, segundo definição do próprio autor, a vários conflitos. Porém, tais conflitos deveriam ser concluídos ao final da novela, para que os seguintes se iniciem.

Outro aspecto da pluralidade de células dramáticas é a relação entre elas. Segundo Moisés, elas teriam relação osmótica, de superposição, o que fica claro quando o autor introduz a idéia de sucessividade. As células se encadeariam numa ordem cronológica e marcada pela substituição dos personagens, que numa célula são coadjuvantes ou secundários, mas que em outra podem se tornar protagonistas, e vice-versa. Ainda conforme o autor, as células não são completamente autônomas, entrelaçando-se ao longo da narrativa, porém Moisés não mostra de que maneira tal interdependência das células dramáticas se realiza.

Segundo Moisés, a temporalidade típica da novela é o presente. Para comprovar seu argumento, o autor usa um trecho da novela $A$ queda dum anjo, de Camilo Castelo Branco, no qual todos os verbos encontram-se no tempo passado. 
Moisés, entretanto, parece enxergar ali outra coisa: "Note-se que as formas de passado ("chegou", "mudou-se", etc.) correspondem ao presente histórico". ${ }^{17}$

Ao que parece, na opinião do crítico, o uso do presente histórico diria respeito ao momento presente, já que ele falava anteriormente justamente na importância do tempo presente na novela. Conduto, sua argumentação, ao invés de corroborar seu pensamento, faz justamente o contrário, pois se o trecho citado, mesmo contendo verbos no passado, corresponde ao presente histórico, então o sentido não é de presente, mas de passado, pois o uso do presente histórico acontece quando nos referimos a fatos passados; a forma verbal usada é o presente, mas o sentido é passado. Por exemplo: Em 1889, Deodoro da Fonseca proclama a República. Nessa frase o tempo verbal é o presente, mas nos referimos a um fato já passado.

O que nos parece mais claro na argumentação sobre o tempo feita por esse autor é a constatação da linearidade cronológica utilizada na novela. Dependente da sucessividade de células dramáticas, a linearidade cronológica faria parte da estrutura básica do gênero novelesco. O tempo dos eventos desenrolar-se-ia, assim, de acordo com o tempo do relógio, exterior, e possuindo também uma horizontalidade na qual os episódios se desenrolariam sem sobreporse. A linearidade cronológica também estaria associada, segundo Moisés, ao princípio de causa e efeito, de fundamental importância num texto literário que depende sobremaneira dos recursos da peripécia e do suspense. Aqui ainda paira a sombra de um leitor que quer ser surpreendido constantemente por fatos inesperados ou que, por outro lado, deseja ver confirmadas suas suposições a respeito do desenrolar da trama.

De forma paradoxal, o lapso temporal percorrido por uma novela é simultaneamente mais restrito e tendendo ao infinito. Por um lado, o narrador já nos oferece as personagens prontas para agir, sem detalhar seu passado, daí a novela abarcar um lapso temporal menor; por outro lado, a sucessão de células dramáticas, com a substituição dos protagonistas por personagens que até então eram secundários, sugere a possibilidade de que essas narrativas nunca necessitam terminar; basta que o autor decida dar ênfase a um personagem que até então permanecera em

${ }^{17}$ Idem, p. 116. 
segundo plano. Para outros autores, como Salvatore D’Onófrio, isso caracterizaria a novela como uma estrutura aberta: "Trata-se de uma narrativa de estrutura aberta, na qual sempre é possível acrescentar mais um episódio, fazer intervir mais uma personagem, deslocar a ação num outro espaço e num outro tempo"18.

A ênfase no momento presente, no tempo cronológico seria ainda, na verdade, um embuste, porque essa presentificação busca mascarar a inatualidade profunda da narrativa:

Destinada a entreter, a novela descura do presente vivo em prol de presentificar o passado, capaz de sugerir devaneio, ou evasão da vida diária. [...] O passado, que se diria conhecido, fornece as novidades; e o presente, morada do imprevisto, é posto de parte. É que o presente real guarda surpresas quando apreendido em câmara lenta, como no romance. [...] A rapidez da ação na novela, pressupõe o conhecimento preliminar das surpresas armazenadas, e por isso, enterradas na memória e na História, mas a fingir que irrompem espontâneas no fio da narrativa ${ }^{19}$.

Por isso, a peripécia (mudança repentina da situação) e o suspense (a interrupção momentânea no fio narrativo que gera expectativa no leitor) são tão importantes na novela. Esses artifícios mantêm a ilusão de os fatos estarem acontecendo naquele momento, quando já estavam previstos desde o começo.

O espaço, numa novela, acompanha as inúmeras ações que a compõem. A ausência de uma unidade espacial estaria ligada às constantes mudanças dos personagens, que se movem sem parar. Entretanto, o espaço não exerce papel dramático relevante, sendo apenas um cenário muitas vezes pitoresco ou fantástico onde transcorrem as aventuras. A pluralidade espacial, decorrente da sucessão de células dramáticas, também é um aspecto em que a superficialidade do gênero se revela, nas palavras de Moisés. O deslocamento dos personagens por espaços fabulosos, por paisagens insólitas atenderia ao apetite imaginativo do público desse texto. Mais uma vez o autor subordina a estrutura do gênero à demanda de emoções fáceis do público.

Um traço que parece constante na estrutura da novela, de acordo com a visão de Moisés, é a ênfase na intriga ou conflito, a tal ponto de se falar em

${ }^{18}$ D’ONÓFRIO, Salvatore. Teoria do texto: prolegômenos e teoria da narrativa. 2.ed. São Paulo: Ática, 2002. v.1, p. 119.

${ }^{19}$ MOISÉS, Massaud. Op. cit., p. 11. 
“intriga pela intriga". O novelista acumula acontecimentos sobre acontecimentos, numa tentativa de encantar o público pela diversidade de fatos apresentados. Tal preocupação diminuiria a verossimilhança do enredo, o que para o autor sempre é um problema, pois, conforme já mostramos, fantasia consiste em fuga da realidade, algo que sempre tem uma conotação negativa na sua concepção. Implicitamente, Moisés parece defender alguma espécie de ligação necessária entre a grande arte literária e uma espécie de realismo ou mimese da vida real. A ênfase na intriga, se encontrada nos ciclos novelescos como Os mistérios de Paris, de Eugène Sue ${ }^{20}$.

O grande número de personagens principais também é apontado por Moisés como típico das novelas. Estruturados de maneira maniqueísta, são na sua maioria planos, com poucos traços e sem aprofundamento psicológico, como requer a dinâmica de uma obra destinada às cabeças menos exigentes do grande público. Os protagonistas vão se sucedendo uns aos outros, à medida que as células dramáticas se sucedem. Assim, uma célula dramática inicia-se, desenvolve-se e termina, e com ela o protagonista é abandonado pelo narrador, que irá acompanhar outro personagem. Este, um personagem secundário noutra célula, torna-se agora o protagonista. Dessa maneira, a novela pode seguir indefinidamente substituindo os protagonistas, refutando o critério da pouca extensão como definidor do gênero; um exemplo famoso são as intermináveis seqüências de Os mistérios de Paris, de Eugène Sue. Também nesse tópico, a novela $O$ minotauro apresenta uma forte divergência com a teoria de Moisés, uma vez que não possui um número grande de personagens.

Moisés parece incorrer numa hierarquia de personagens feita a partir da quantidade de traços psicológicos e na evolução dos mesmos. Assim, quanto mais unilateral ou plano for o personagem, menos valor ele terá; e por conseqüência, quanto mais complexo, melhor. Tal classificação dos personagens estaria na base da hierarquização das narrativas, antecedendo-a: se uma narrativa - conto, novela ou romance - não possui personagens complexos ou explora em profundidade seus caracteres, esta já se torna necessariamente inferior. É claro que Moisés desvia a atenção do leitor, ao considerar tais textos literários como narrativas para um públi-

${ }^{20}$ In: http://gutenberg. Org/etext/18921. 
co menos exigente. De fato, trata-se de um eufemismo que esconde sua verdadeira opinião: as novelas, por não explorarem em profundidade seus personagens, constituiriam um gênero literário menor, destinado à distração, à alienação.

Na concepção de Moisés, o ponto de vista mais adotado nas novelas é o dos narradores oniscientes e unívocos, pois, para acompanhar o imenso número de personagens, seria estruturalmente perturbador mudar a cada momento a perspectiva da narração. Essa preferência pelo foco em terceira pessoa onisciente é criticada pelo autor como sendo inverossímil o narrador ver tudo e estar em toda parte: "Mas essas limitações não afetam o leitor comum, interessado no desfile das peripécias e pouco atento à inverossimilhança decorrente da faculdade que o narrador se arroga de ver tudo e estar em toda parte". ${ }^{21}$ Isso contraria o senso comum; afinal de contas, não é uma convenção da narrativa esse tipo de narrador encontrado tanto em romances quanto em contos? A nosso ver, até mesmo aquilo que não é em absoluto característico da novela, quando presente nesta, torna-se um sinal negativo. Também é necessário, tendo em vista o público, o narrador não 'perder tempo' com problematizações de ordem metalingüística ou longas digressões: urge ir direto ao ponto, e o ponto numa novela é a ação.

$\mathrm{Na}$ análise da linguagem usada na novela, Moisés afirma que ela é o mais simples, direta e objetiva possível e acompanha a ênfase na ação, típica desse gênero. Mais uma vez, o autor reafirma a importância da ação como elemento definidor na constituição da novela e que interfere em todos os outros elementos estruturais. O lirismo e as figuras de linguagem devem ser bastante dosados ou convencionais, para não interromper o moto-contínuo da narrativa nem perturbar a compreensão. É então uma linguagem 'pouco poética', pelo menos de acordo com a concepção mais clássica do fazer literário, segundo a qual há uma distância entre a linguagem do cotidiano, mais direta, e a linguagem literária, mais carregada de recursos expressivos.

Não se deve supor, por isso, que a novela seja, para Moisés, 'realista', no sentido de arte preocupada com a verossimilhança, com a denúncia dos problemas sociais. O realismo das novelas é convencional, esquemático, preocupado com os aspectos mais óbvios do real. Assim, quando há certo enquadramento sócio-históri-

\footnotetext{
${ }^{21}$ MOISÉS, Massaud. Op. cit.
} 
co na novela, é para servir de pano de fundo das fabulações mirabolantes da narrativa. "Com o virar as costas à realidade concreta, o novelista isola a ação, cortandolhe os liames com as circunstâncias: nega o intercâmbio entre as várias facetas do poliedro social e natural, com vistas a realçar os móbeis da ação" 22

Na conceituação que dá à novela, o autor afirma que esta "ilude e mistifica"23; esse é o ponto de vista de alguns filósofos sobre o mito, tido como um relato falso, mentiroso, em contraposição à "história" - o relato do real, da verdade ${ }^{24}$. Assim, percebe-se sub-repticiamente na argumentação de Moisés uma equivalência entre verdade/análise psicológica/romance, por um lado; e por outro, mentira/superficialidade/novela.

De fato, há implícita uma teoria sobre a arte literária, que teria como ápice a forma/o gênero romance, ficando assim a novela como uma forma narrativa incompleta, pois incapaz de penetrar os recônditos da alma, onde estaria a verdade do ser humano. Talvez ainda exista certo dualismo latente nesta concepção, porque reduz tudo a um jogo: na aparência, na superfície, a mentira; e na profundidade, a essência, a verdade. É dessa perspectiva que o autor afirma que as novelas não perduram, são esquecidas; e apenas aquelas que transcendem as características do gênero permanecem.

A novela, segundo Moisés, vale-se dos "recursos da técnica, empregados na comunicação de episódios superficiais e aventurescos". Após a invenção do romance, a novela tornou-se atividade marginal e popularesca, em que pese a sua presença ao longo do século XIX e a existência de alguns novelistas de alto nível. $\mathrm{Na}$ visão do autor, a novela é a soma de gestos encadeados na ordem linear do tempo, induz a pensar que a realidade não seja polimórfica ou enigmática, nem que ostente relevo e complexidade. Pressupondo-se que tudo se conheça, ou que se converta em atos e acontecimentos visíveis, a novela contempla, não indaga; finge, não questiona; fantasia, não interroga.

\footnotetext{
${ }^{22}$ Idem,ibidem.

${ }^{23}$ Idem, p. 112.

${ }^{24}$ Segundo Mora, "Vários autores modernos negaram-se a considerar os mitos como dignos de menção; a 'verdadeira história', proclamaram eles, nada tem de mítico. Por isso, o historiador deve depurar a história de mitos e lendas" (MORA, José Ferrater. Dicionário de filosofia. São Paulo: Martins Fontes, 2001, p.479).
} 
A narrativa mítica, entretanto, também não se detém na análise psicológica dos heróis, mas na descrição (ou no relato) de seus feitos; mesmo assim, há tradição de leituras antropológicas e psicanalíticas do mito que mostram a extrema complexidade e motivação psíquica dos personagens envolvidos nos fabulosos acontecimentos narrados. Esse fato desmentiria a idéia de Moisés, segundo o qual, um dos defeitos da novela seria essa superficialidade psicológica, assim como a ênfase na ação e nos acontecimentos. Ora, os mitos concentram-se sobre fatos bastante distanciados, pelo caráter maravilhoso, do cotidiano.

\subsection{Breve histórico da novela}

Segundo a proposta de Moisés, as novelas dividem-se em cinco tipos: de cavalaria, sentimentais ou bucólicas, picarescas, históricas e policiais ou de mistérios. Essa classificação obedece a um critério temático. As de cavalaria originaram-se no século XII, na França, a partir da prosificação das canções de gesta; seu tema são os feitos guerreiros e os valores como coragem, verdade e lealdade dos heróis reproduzem a visão de mundo da nobreza feudal.

Por volta do século XVII, entra em decadência esse tipo de narrativa, que vai sendo pouco a pouco substituída pelas novelas sentimentais e bucólicas. Os temas agora são a descrição da natureza e a narração de idílios entre pastores. Avulta o lado sentimental, em detrimento dos antigos valores cavaleirescos; esteve no auge durante o século XVIII, com a voga neoclássica proporcionada pelo ócio burguês.

Por essa época também surgem novelas picarescas. Seu nome vem do herói o pícaro, "criatura de vida irregular, vadia, empregada de sucessivos patrões e vivendo de expedientes astuciosos e inescrupulosos para saciar sua fome de miserável" 25 e narra suas peripécias.

A novela histórica inaugura, com o Romantismo, as incursões dos autores à Idade Média ou ao passado recente, só que de maneira sentimental e idealizada. Revela uma concepção problemática: por um lado, os autores pretendem a verda-

${ }^{25}$ MOISÉS, Massaud. Op. cit., p.139. 
de histórica; por outro, os lances imaginativos e fantasiosos transportam essas narrativas para as raias do mito.

A segunda metade do século vê surgir um novo gênero de novela, a policial ou de mistério, ainda em voga até hoje. Esta é identificada por um crime em cujo desvendamento se empenham detetives (policiais) ou, quando estes não aparecem, de mistério. É nessa classificação que $O$ minotauro poderia se enquadrar. Aqui, mais uma vez, o eminente crítico demonstra certo desprezo por esse gênero, considerando-o "subliteratura" devido a seu aspecto popularesco de diversão e evasão barata do 'masoquismo do homem moderno' .

As observações apresentadas nos parágrafos anteriores constituem uma releitura crítica da teoria apresentada por Moisés . As considerações desse autor sobre a novela serão usadas desde que se harmonizem com uma noção mais discursiva do gênero. Em nossa análise do corpus (capítulo 3), procuraremos incorporar aos elementos estruturais que nos pareçam constantes na novela as noções de carnavalização e hibridismo encontradas na obra de Mikhail Bakhtin. $\mathrm{Na}$ perspectiva bakhtiniana, nenhum gênero é estanque nem possui uma essencialidade histórica: há um intenso processo dialógico de troca de elementos composicionais entre os gêneros, redefinições, englobamentos.

Não é nosso interesse construir uma teoria fechada do gênero novela. Procuramos, com as observações que se seguiram, sugerir outros modos de abordar o texto novelesco sem nos restringirmos apenas aos elementos estruturais, como enredo, personagens, espaço etc. Tal teoria será abordada em trabalho posterior. Nesse texto, apenas mostramos o quão confusa e limitadas são as teorias que procuram dar conta desse gênero, mas que, ao cabo, não o fazem. 